\title{
The academic turn: Social media in higher education
}

\section{Thirusellvan Vandeyar ${ }^{1}$ (D)}

Received: 14 February 2020 / Accepted: 28 May 2020 / Published online: 4 June 2020

(C) Springer Science+Business Media, LLC, part of Springer Nature 2020

\begin{abstract}
Universities must transform to fulfil expectations of the knowledge society. At the same time academics are required to respond to the dynamic environment that information and communications technologies (ICT) bring to effective and efficient teaching methods. Utilizing a qualitative case study approach, this study set out to explore experiences of academics' as they made a pedagogic turn towards using social media technology for teaching in a resource-constrained context. The Technology Acceptance Model served as the theoretical mooring of this study. Data capture included a mix of semi-structured interviews, classroom observations, document analysis and field notes. Findings are presented as three academic turns. First, a turn away from the institutions' LMS due to contextual exigencies. Second, a pedagogical turn towards Web 2.0 technologies using social media tools to enhance their pedagogy. Third, a beliefs and attitude turn about the affordances of social media; augmenting academics' resilience to persevere with this technology of choice. This study recommends that the use of social media networking in higher education creates a viable form of technology enhanced teaching, particularly in resource-constrained contexts. Further studies should explore academics emerging pedagogical practices in their use of social media, and students' perceptions and engagement in social media learning communities.
\end{abstract}

Keywords Academic turn · Higher education · Innovation · LMS · Resilience · Web 2.0

\section{Introduction and background context}

The introduction of ICT brings forth new opportunities for academics in higher education institutions (HEI's) to reconfigure the way they conduct their business of facilitating teaching and learning. The rapid pace of change in technology innovation and development demands that HEI's are always in a state of flux (Kukulska-Hulme

Thirusellvan Vandeyar

thiru.vandeyar@up.ac.za

1 Department of Science, Mathematics and Technology Education, Faculty of Education, University of Pretoria, Leyds Street, Pretoria 0002, South Africa 
2012). The advent of the Fourth Industrial Revolution (4IR), witnessed the emergence of robot tutors and chatbots, which offers new possibilities for universities to engage with students. This dynamic transition to an ICT intensive environment creates a world of 'complexity' and poses overwhelming challenges for academics to reconceptualise their teaching (Mostert and Quinn 2009, p. 72). In order to be relevant, academics must acquire additional skills and teaching methods concomitant with ICT integration such as, blended learning, hybrid learning, e-learning, augmented reality (AR), virtual reality (VR), flipped classrooms and so forth (Protsiv and Atkins 2016). Although HEI's may respond to the need for ICT technical support for academics (Mostert and Quinn 2009), the more serious issue is that ICT integration requires academics to reconceptualise their pedagogical practice (Tess 2013). This means that academics require much more than the mere acquisition of various pedagogical knowledges as delineated by the Mishra and Koehler's Technology, Pedagogy and Content Knowledge (TPACK) model (Cubeles and Riu 2018; Mishra and Koehler 2007). Furthermore, the Covid19 pandemic has catapulted the urgency and dire need for using online tools to the forefront of its significance to continue teaching and learning activities. Nationwide closures of educational institutions are impacting over $91 \%$ of the world's student population. The Vice-Principal of a South African university stated "We are trying our best to address the unprecedented demands of online educating while social distancing. Universities are now faced with the biggest challenge presented by the pandemic, and that is the need to move teaching and learning online immediately" (Naidu 2020, p.1). In this regard many academics are caught on their backfoot, in not seizing the opportunities presented by social media tools for teaching online.

In the context of Uganda, a developing country, the introduction of ICT into mainstream education is intended to transform teaching and learning in higher education institutions. However, the integration of ICT is inhibited by typical developing countries exigencies namely, inadequate access to relevant technology, erratic power supply, lack of supporting policies, internet infrastructure and high cost of internet, among other contextual issues (Maleko et al. 2011). Though research on ICT in universities is apparent, there is a dearth of research that focuses specifically on the use of social media in the teaching-learning space (Tess 2013), and even less research on its influence in the higher education teaching context of developing countries (Sobaith et al. 2016). Accordingly, this study asks how do academics integrate ICT in their practice in a developing country? How do academics utilise social media to make a pedagogical shift? What beliefs, perceptions and attitudes do academics hold about the integration of ICT in their practice? Thus, the purpose of this study is to explore how academics' make a pedagogical shift in their use of ICT, and to address the identified gaps in the empirical literature (Chugh and Ruhi 2018; Manca 2020).

\section{Exploring the literature terrain}

A review of the voluminous literature yielded a few themes namely, ICT trends in higher education, learning management systems (LMS) and the role of academics as instructional designers, social media in higher education, and academics' underlying beliefs and attitudes about the use of ICT in higher education. 
ICT in higher education has transformed the coalface of higher education learning and teaching. Increased internet connectivity has led to increased access to higher education learning through massive open online courses (MOOCs), virtual-classrooms, online and open universities. This pervasive access to online universities is growing unabated and traditional higher education institutions have to respond by providing lifelong learning opportunities for students to study at their convenience, regardless of place and time (Harris et al. 2009). The ubiquity of technology has also enabled access to education for distance students, socio-economic disadvantaged students and disabled students. Furthermore, ICT offers new ways of delivering a flexible, customised education suitable for differentiated learning environments to anyone, anywhere, and anytime. Englund et al. (2017) indicate that though ICT has made significant inroads into universities, its widespread use by academics has not yielded the requisite conceptual changes to traditional modes of teaching. This is disappointing because the envisaged potential of ICT to transform teaching in higher education is being missed or at worse resisted (Al-Senaidi et al. 2009). A study conducted by Davies (2011) found that there has not been much progress on academic's integration of ICT into their teaching practice. Less than one third of faculty adequately prepared to incorporate ICT into their teaching practice. Furthermore, faculty training seemingly does not promote the integration of ICT as an integral component of curriculum delivery (Garner and Bonds-Raacke 2013). The extant literature (Cubeles and Riu 2018; Hue and Jalil 2013; Gaffar et al. 2011) suggest that the use of ICT has not effectively transformed teaching and learning in higher education institutions.

The growing use of learning management systems $\left(\mathrm{LMS}^{1}\right)$ in universities seems to favour basic academic skills sets and institutional ICT transformation (Johnson et al. 2016). Although universities have invested significant, financial and human resources, academics have used the LMS merely as a repository for subject materials and information sharing (Cabero-Almenara et al. 2019). Most LMS features that may promote a pedagogical shift to constructive teaching remains limited or non-existent. Saunders and Klemming (2016) argue that the transition an academic has to make from teaching in a face-to-face traditional classroom setting to a virtual online teaching environment requires 'curriculum designer', 'instructional designer' and 'technical designer' skill sets. However, it may be a challenge to find academics with an ICT profile that comprise these requisite designer skills, given that in some cases academics become lecturers without any pedagogy training. There seems to be a dearth of literature about academics' engagement with learning management systems (Beer et al. 2009) as well as the affordances that LMS brings to academics changed pedagogical practice (Coates et al. 2005). The adoption of new technological approaches in teaching can be a daunting task for academics and may result in a tradeoff through sacrificing a research-intensive focus for a teaching focus. Academics have to be compliant with the digital transformation ethos of higher education institutions in order to be relevant and competitive. Thus, they have to transcend the difficulties of using new technology within the time constraints and become change agents by adopting the belief that ICT has the potential to enhance student learning (Akbar 2016).

\footnotetext{
${ }^{1}$ Learning management systems (LMS) are online tools servicing mostly higher education institutions with various teaching-learning functionalities namely, knowledge sharing, content management, discussion boards, learners' interaction, communication and assessment. (Cabero-Almenara et al. 2019)
} 
A current trend that is emerging in higher education is the role that social media plays in the teaching-learning context (Manca 2020). Recent research suggests that despite the proliferation of Web 2.0 technology, academics have not embraced the opportunity to use this technology to support their pedagogy, content delivery and assessment (Chen and Bryer 2012; Manca and Ranieri 2016). Students, on the other hand, being avid and apt users of social media favour the use of social networking, although mostly for social engagement than for educational purpose (Guy 2012). In contrast, evidence suggest that faculty seem to be more 'cautious' and less willing than students to use social media, particularly for teaching (Piotrowski 2015, p. 3). The influence of social media on academic practice indicate that academics are ambivalent about the role that social media should play in teaching and learning. In light of this Stathopoulou, Siamagka and Christodoulides (2019, p.422) indicate that faculty members have been "advised to keep a balance in terms of relevance of social media use, control, and usage level" of social media platforms. Although some studies (McAliney 2013; Stathopoulou et al. 2019) suggest that academic interest in the use of social media for instructional purposes, most research indicates that academics are averse to its use (Manca and Ranieri 2016; Selwyn 2012). In this regard, academics believe social media is a form of disruptive technology that does not promote student learning (Friesen and Lowe 2012), while others believe that social media blurs the boundary between personal use and academic use (Tang and Hew 2017; Lenhart et al. 2010). Academics lack of personal use of social media tools is also touted as another factor contributing to their indifference to its educational value (Guy 2012). Some contextual factors inhibiting academics use of social media for teaching are attributed to; time constraints, high workloads, cyber security and bullying, privacy and lack of appropriate assessment strategies.

Guy (2012, p. 12) indicates that critics of social media are "calling for regulations and/or the removal of such technologies" for educative purposes. In cases where social media tools were utilised for academic purposes, this seemed to be limited to activities such as submitting assignments, or self-driven reinforcement activities (Guy 2012; McCarthy 2009). However, proponents of social media in higher education concur that its affordances can translate positively into participatory learning (Manan et al. 2012; Manca 2020; Duta and Martinez-Rivera 2015), self-reflection and social interaction (Deng and Yuen 2011), and improved student engagement and communication skills (Lederer 2012). The ubiquity of social media in higher education may transform teaching through collaborative learning, flexible learning environments and interactive user-centred learning (Amin and Rajadurai 2018). Despite these benefits of social media for learning, there are inherent concerns in higher education institutions about the use of social media in teaching and learning. First, that it is a type of disruptive technology that challenges traditional teaching approaches (Ratto and Boler 2014); second, that students' perceptions about using social media tools must change to 'this is where I study' (Bolat and O'Sullivan 2017, p.744); third, although social media allows for flexible distance and online learning, reducing time and space constraints of access to education, cognisance must be taken of socio-economically disadvantaged students who may be unable to access social media tools for learning (Nayar and Kumar 2018); and fourth, social media challenges power-relations and rigid hierarchical structure in universities (Larsson and Kalsnes 2014).

Research (Hue and Jalil 2013; Thorvaldsen and Madsen 2020) posit that the integration of ICT into the academics' pedagogic practice is a complex process. Given 
that teaching itself is a complex process (Loughran 2013), technology integration should not only focus on academics' knowledge of technology, curriculum and pedagogy (Mishra and Koehler 2007), but significantly also consider academics' attitudes (Ertmer et al. 2012). Against the myriad of important issues to be considered in the integration of technology, research pinpoints academics' attitudes as the single most important factor (Albirini 2006). Seemingly, it is not the nature of the technology, or access to technology that inhibits or promotes ICT integration, but academics' beliefs and attitudes that are at the heart of the problem (Renes and Strange 2011). Tearle's (2004) ICT integration model places subjective norms, beliefs and attitudes at the core of an academic's intention to use ICT in practice. Teacher's pedagogical beliefs are at work in our quest to understand successful technology integration. Ertmer's (Ertmer et al. 2012) nascent work on teachers' beliefs identified first order changes such as ICT access, ICT preparedness and curriculum freedom as issues that may be easily resolved. However, teacher beliefs about ICT use and integration is not so easy to understand and resolve. Second order 'beliefs' challenge academics to reconceptualise technological infused ways of "seeing and doing things". Beliefs as second order changes are pivotal and of particular interest in this study, because it is irreversible and prevents a person reverting to previous routines of traditional teaching. According to Ertmer et al. (2012) fundamental change to use ICT in constructive ways, may only occur if academics' inherent attitude about role of technology is concurrent with their practice. To research academic's use of technology in teaching, we have to distil what they say (beliefs) as opposed to what they actually do (practice).

\section{Theoretical scaffolding}

Davis' (1993) Technology Acceptance Model (TAM) underpins this study as a theoretical framework. The TAM represents a good fit within a constructivist metatheoretical paradigm, as it presents individual attitudes and subjective choice for using (or not using) ICT for teaching and learning. Two distinct attitude constructs namely, 'perceived usefulness' (PU) and 'perceived ease of use' (PEU) are used to frame the attitude of the academic towards engagement or indifference to the use of technology. These two behavioural constructs namely PU and PEU also directly influence whether actual engagement with the technology will occur.

Davis (1993) defines perceived usefulness as the extent to which an academic perceives that their use of the technology would facilitate or enhance their work performance, the emphasis of perceived usefulness (PU) is on improved job productivity and effectiveness. Davis identifies the construct of perceived usefulness as the affordances that ICT brings to teaching; First, would the use of technology result in accomplishing the task more quickly? Second, would it improve or enhance their job effectiveness? Third, would the end user of the technology find the task easier to perform? Fourth, and most significantly, would the end user find it useful?

The second construct of the Technology Acceptance Model namely, perceived ease of use is described as the degree to which the user may appreciate that the use of technology would be both mentally and physically effortless. The emphasis of the PEU construct is on the amount of effort the academic will have to exert to use the technology innovation. Davis (1993) describes perceived ease of use as being easy to 
interact with, understandable and flexible to use. Ease of use also implies that the academic must develop a skill set or competence in the use of social media technology (Dumpit and Fernandez 2017). Although environmental context, type of technology, and institutional mandates should be considered as additional criteria in research on the TAM model. Rodriguez (2012) argues that attitude is the key construct that determines the user's assessment of how the target system would benefit job performance.

\section{Research strategy}

A social-constructivist researcher lens that views knowledge as being socially constructed by individuals to make meaning of their experiences was used as the meta-theoretical paradigm to frame this study. The case is bounded by its particularity to academics at a public university in Uganda. This qualitative instrumental case study (Stake 2005) attempts to provide insight into the "little understood" phenomenon of social media use by academics. The study was exploratory and thus may or may not be typical of other cases, as focus was on the peculiarity of the case and not intended to draw generalisation of the findings.

Data collection methods included semi-structured face-to-face interviews as the main data collection method (Denzin and Lincoln 2011). Classroom observations of academics' practices were conducted with the researcher as a reactive observer. Both classroom observations and document analysis addressed triangulation of data, to verify what participants say they do may not necessarily be what they actually do in practice (Argyris and Schön 1974). The participant interviews and class observations took place over a period of ten months (2018-2019) and continued until saturation of data occurred. Member-checking (Creswell 2012) allowed for the researcher to revisit participants to clarify issues captured in transcripts to "check for accuracy" and interpretation. The unit of analysis was represented by the purposeful selection of one academic from each of the seven faculties at Lethlolo University (Table 1).

Table 1 Demographics of participants

\begin{tabular}{|c|c|c|c|c|c|c|}
\hline Pseudonym & Academic rank & $\begin{array}{l}\text { Highest } \\
\text { qualification }\end{array}$ & Gender & Age & $\begin{array}{l}\text { Number of years } \\
\text { in HEI } \\
\text { (experience) }\end{array}$ & Subject specialisation \\
\hline Madula & Senior Lecturer & $\mathrm{PhD}$ & Male & 35 & 9 & $\begin{array}{l}\text { Human Resources } \\
\text { \& Business } \\
\text { Management }\end{array}$ \\
\hline Aloket & Lecturer & MSc & Male & 35 & 9 & Business Computing \\
\hline Kaelo & Lecturer & MSc & Female & 36 & 8 & $\begin{array}{l}\text { Procurement and } \\
\text { Logistics }\end{array}$ \\
\hline Muso & $\begin{array}{l}\text { Associate } \\
\text { Professor }\end{array}$ & $\mathrm{PhD}$ & Male & 48 & 18 & Entrepreneurship \\
\hline Makaila & Lecturer & $\mathrm{MSc}$ & Female & 35 & 10 & $\begin{array}{l}\text { Computing } \\
\text { and Management } \\
\text { Science }\end{array}$ \\
\hline Tuba & Senior Lecturer & $\mathrm{PhD}$ & Male & 40 & 19 & Tourism \\
\hline Kyati & Assistant Lecturer & MSC & Male & 39 & 8 & Graduate studies \\
\hline
\end{tabular}


Most garnered data were converted into text, which was the primary source of manual coding and interpretation through content analysis. Through the iterative, reflective and interactive content analysis process, priori themes emerged (Saldana 2012). The coding and analysis process were further subjected to distillation to enhance coherent themes. Five themes emerged from the coding of data namely; existing pedagogical practices, pedagogical paradigm shift, ICT as a catalyst for professional development, perceived challenges and opportunities in the use of social media. The table below is a representative sample of the two themes and the sub-categories relevant to this paper (see Table 2).

While this study has provided some positive insights, it is not without limitations. The participant sample could have been selected from a larger and more representative academic population from other universities located in Uganda that would render the findings to be objective. Inter-rater reliability could have been employed to enhance content analysis rigour in the coding and theme coherency.

\section{Findings}

The themes are represented as academic 'turns' to portray the transition made by academics to integrate ICT into their teaching practice. The first 'turn' identifies academics' abandonment of the institutional learning management system. A second 'turn' illustrates the technology shift they made to using social media platforms to enhance their teaching and evolve their own pedagogical approach. The third 'turn' represents the resilience experienced by academics to pursue the integration of social media in their practice.

\subsection{The 'turn' away from an LMS}

This theme unfolds to describe academics' ambivalence towards the Moodle learning management system. First I describe the 'pull factors' of the affordances that the LMS

Table 2 Some emergent themes

\begin{tabular}{ll}
\hline Theme & Categories \\
\hline Existing ICT pedagogical practices & - Reliance on proprietary software \\
& - The ambivalence towards a Learning Management System (LMS) \\
ICT Pedagogical paradigm & - A shift to Web 2.0 technologies for teaching and learning: \\
shift - changed teaching practices & - Social media - Facebook \\
& an interactive learning resource, \\
& a LMS \\
& a live broadcast tool \\
- Social media - Blogs & Blogs as collaborative spaces \\
& Blogs as a form of reflective practice \\
- The evolving pedagogical role of academics & Perceptions of changed students' attitudes \\
\hline
\end{tabular}


brings to academics' work. Second, I describe the 'push factors' experiences that caused academics to 'turn' away from the institutions LMS.

Participants in this study believed that the LMS offered advantages to simplify most of their administrative tasks in ways that would make teaching and learning more streamlined, systematised and organised. These academics used the university's LMS to change the way they facilitated their classes. Participants in this study began by adopting the LMS for administrative task-related to dissemination of course materials with limited use for enhancing learning. The perceived usefulness of the LMS to facilitating teaching in an online environment seemed to have caught the attention of academics (Revythi and Tselios 2019). Academics viewed the LMS as a tool that supports innovative administrative approaches to the delivery of course materials for teaching and learning.

Academics argued that the LMS was key in facilitating discussions and communication in the teaching process. The perceived ease of use was that the LMS was a comprehensive platform in which they could interact and share information with students. The LMS offered them much administrative control in the manner in which they could deliver the course content,

And one of the most significant things is that the academic has control over student material and the direction of the discussion. When students are submitting assignments, they do so online [LMS] and then when I want to give submission deadlines, the incorporation of ICT is to limit the time available so that when the deadline comes the system automatically rejects further submissions (Madula).

The Moodle LMS tool was a platform for the management and administration of elearning. Academics could upload subject material and enroll students to their courses that promoted communication and interaction between the lecturers and students. An academic indicated that the LMS platform was useful in managing coursework assignments, but also realised that the LMS was a useful tool to support and supplement the teaching process (Fig. 1).

I use it to send and receive communications, comments between me and the students... on some occasions, I use it as an avenue to discuss with my students' pertinent issues and in other cases, I want to check on their involvement in the course on the LMS (Makaila).

Some academics appreciated the LMS because they did not have to travel from one campus to another. The LMS provided an opportunity to teach from a distance, yet in a collaborative way, I do not incur costs moving from one campus to another because I can conduct my lectures online via the LMS (Tuba).

Although the use of the LMS was relatively new to academics, some believed that the online system enhanced new pedagogical approaches. Academics describe how the 


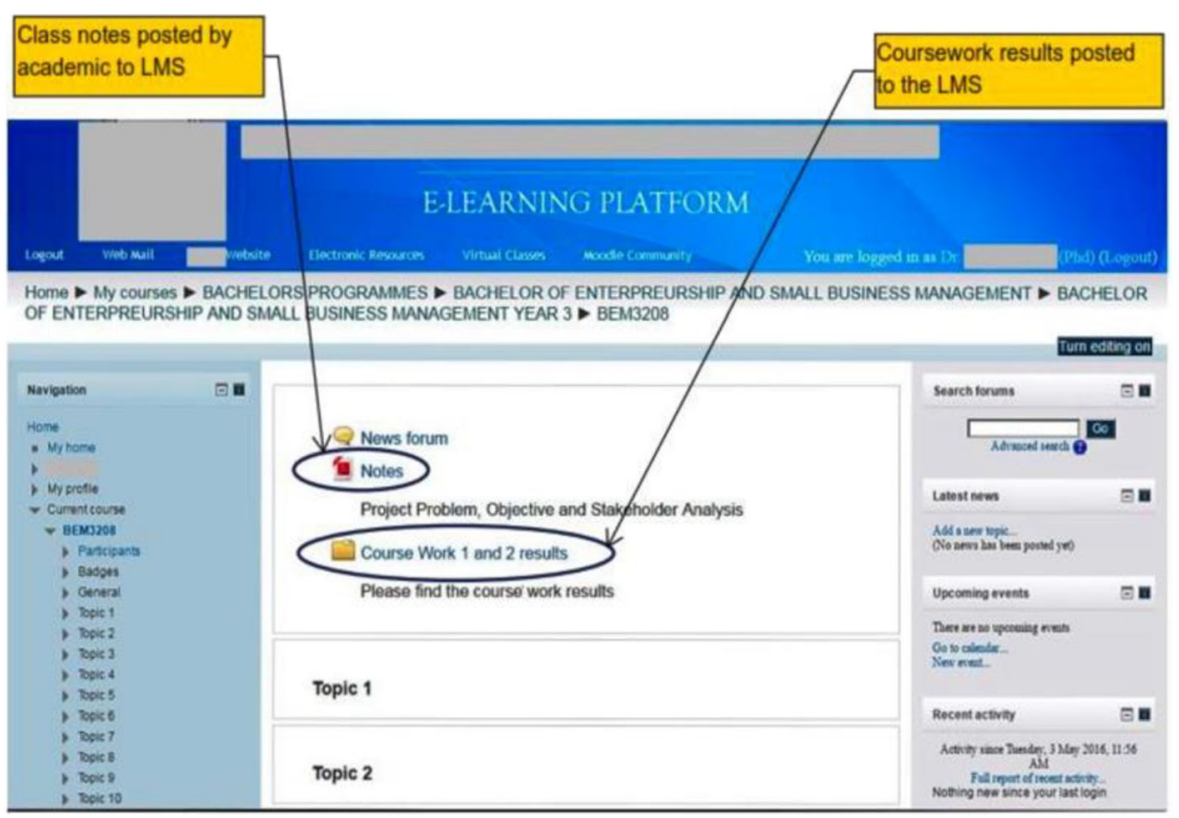

Fig. 1 Screen capture of e-learning platform (LMS): business management

LMS has tools that allows for embedding of multimedia content to enrich their teaching,

I can also use various media like integrating audio and visual to deliver my lectures through the LMS, which makes students understand faster and saves me time...It is possible for me to do presentations, have separate chats during presentation, and have audio ... all on the LMS (Muso).

All academics shared the view that the LMS was used primarily for routine function that saved time in the delivery of course material and administration of the course. They indicated that this platform played a major role in saving valuable time to engage in other productive activities. Academics alluded to the fact that the asynchronous scheduling of classes was convenient for both lecturer and students. They found that the use of the LMS saved time, that would have been wasted through setting up face-toface class meetings,

It is convenient for me and the students and that means less face-to-face interaction with students as this can be arranged through the LMS, it is possible to schedule class discussions ... and this saves you the time wasted doing "leg work" when trying to set up or agree on an appropriate meeting time ... so it's a good thing (Muso).

Although many of the academics were enchanted with the administrative advantages that the LMS offered in facilitating their teaching, they seemed to hold higher expectations of the LMS. Within the context of this study, the findings suggest that 
academics had higher expectations of the LMS. First, academics had reservations about the usefulness of the LMS to change their teaching pedagogy. Second, they experienced the LMS as a work intensive system, that was a burden, and a waste of time and effort. Third, they experienced the LMS as unreliable and not user friendly. And fourth, it was fraught with student apathy.

Academics were disillusioned with the affordances that the LMS offered to enhance their teaching practice. Though they did not use all the different features and tools of the LMS, they felt that it offered little opportunity to change his pedagogical practice. It only enables more interactions with the students prior to and after their classes... other than communication, the LMS has made no significant effect to the course... as for the teaching process, I don't see much of a difference (Kyati).

Some academics experienced the LMS as a burdening system. They complained that it took longer to accomplish tasks that were intended to be easy. The introduction of the LMS into their teaching practice seem to make their entire teaching process more complicated and seemingly increased their workload. Furthermore, the LMS required more time and effort to prepare and engage with students in online discussion activities, thus discouraging them from using it consistently. Academics seemed to suggest that the LMS required much time and effort and would incur other important academic trade-offs,

Yes, I encourage my students to engage in these discussions. However, it is challenging since it requires that I spare some time to be available for the discussion with the students, it means I have to scale down on the other activities like research supervision.

...Time is usually the biggest challenge I would think, there is too much administrative work that is not about to go away any time soon and all this eats up on my research time (Muso).

The Moodle system's stability and reliability were a major concern for the academics in this study Academics were frustrated with the operational aspects of the LMS. The system was often inaccessibility due to the system malfunctioning or under development. Some academics were apprehensive that the technology would not be functional at the most crucial time of need. Others, indicated that logging onto the LMS platform required patience, often resulting in failed attempts,

It [LMS] is on and off. Sometimes you are not sure if it [LMS] is working and therefore students will use it as an excuse for not completing their online assignments. The LMS in place is not user friendly. Many times I am motivated by something that is friendlier, convenient and reliable than something that is complicated and unreliable ...but I hardly use it any longer for the reason that it failed to work the time I wanted to use it, I am stuck to just dealing with my students face-to-face (Kaelo). 
In order to login into the LMS, users need to be very patient since it takes a long time .... the time spent when logging into the system is too much and this discourages many would-be users (Aloket).

Academics felt that the main disadvantage of the LMS was student apathy. Students invariably only participated in discussions, if it was mandatory and commensurate with a grade being awarded for participation. Academics also found that students did not view the LMS as an extension of class, thus they did not see it as an alternative means to participating in online discussions. A major issue for academics was that students did not want to embrace the LMS technology and refrained from LMS mediated discussions.

They [students] are reluctant...hardly post anything to the platform ... only when a course work score is attached do we get to see some tangible input, reason being that if they don't participate then it is likely that they will get a poor grade, or worse, fail ... however, when the choice is theirs to make without any form of compelling, they will not make any effort (Muso).

Students do not participate that much ... and this provided a bad experience for me

... so I hardly think about using it [LMS] on a regular basis (Kaelo).

Thus, the discontentment experienced by academics led to their 'turn' away from the learning management system and a re-'turn' to traditional teaching practices.

\subsection{The 'turn' towards social media}

Academics voices suggested that social media technologies presented a more effective way of using information and communication technology to enhance their practice. A number of reasons were attributed to the academic turn towards social media. First, academics claimed that social media transformed their teaching because it was effective, promoted interactions and ideally suited to teaching smaller classes. Second, social media promoted learning through inherent advantages in that it was easy to use, it could synchronously deliver course content, promote online discussions, and facilitate student engagement remotely. Third, social media was free, user-friendly interface and technical setup, and ease of connectivity motivated academics as well as students to adopt it as a teaching-learning platform. Fourth, participants seemed to prefer this mode of synchronous transmission because they received instantaneous feedback from students. Significantly, the ubiquity of social media allowed for teaching to take place almost independent of space and time constraints.

Academics relished social media as a teaching technology tool of choice. They felt that it enhanced their teaching practice. Furthermore, teaching through a social media context varied significantly from the traditional constraints of the classroom environment. Academics noted that students were not keen to ask questions during face-to-face classroom interactions, but in the online environment, discussions flourished. They felt 
that the adoption of social media emergent technologies catered for a twenty-first century learner. This method of teaching encouraged students to engage with the subject content, and at the same time afforded academics the opportunity to discern whether students understood or required additional support.

I just tell student to use Google and find this subject or go to Facebook and look at this page and tell me A, B, C, D. Students are more interested in completing an assignment on Facebook or the internet and are more prepared to do it than sit in the library and flip pages .... yah (Kaelo).

Academics' were comfortable with the transition to social media as a means to changing their teaching practice. They believed that the proliferation of networking technologies and software tools presented new opportunities for academics to make use of streaming digital video in their teaching practices. The Facebook Live features were easy and more convenient to use to communicate. Initially, academics were reluctant to make use of this technology because they were uncertain of how it would work in a teaching context and whether their students would embrace this technology as a new form of course delivery.

I was quite nervous the first time I tried it. I had agreed with the class [students] on the time I would go live on Facebook and surprisingly 20 students out of a class of 43 were logged-in when I started streaming... ohhh my God! I shouted to myself, it works! It works! From reactions in the form of comments that were scrolling over the screen, I could sense the excitement from my students as well. It was a new experience for many of my students, even for me (Makaila).

Many academics also found students responded more positively to the use of social media for learning purposes. The social media online context presented a user-friendly environment for both lecturer and student. For example, the social media platform of Facebook encouraged student engagement, inquiry and interest. Students were appreciative of this form of synchronous learning and requested an academic to try the Facebook Live feature for his classes. This new approach to teaching slowly became part of this academic's teaching repertoire,

In one of our face-to-face class interactions one of the students asked, "Why don't we use Facebook Live for some of our discussions?" I enquired from students as to how many of them would be able to join the conversation, if we agreed on the session time. The numbers that responded positively overwhelmed me. I tried it out (Aloket).

Student responses to academics' use of Facebook Live social media were encouraging. In the online mode of teaching (Fig. 2) students responded with "thumbs-up" or the "heart" emoticons, or short comments such as "you answered my question in this episode", "what a nice idea" and "thanks for the self-audit lesson." Furthermore, In the contact lectures that followed live stream sessions, students expressed their appreciation to lecturers. Academics believe that Facebook Live was a convenient medium to engage with students because it occurred in a more relaxed environment, away from 


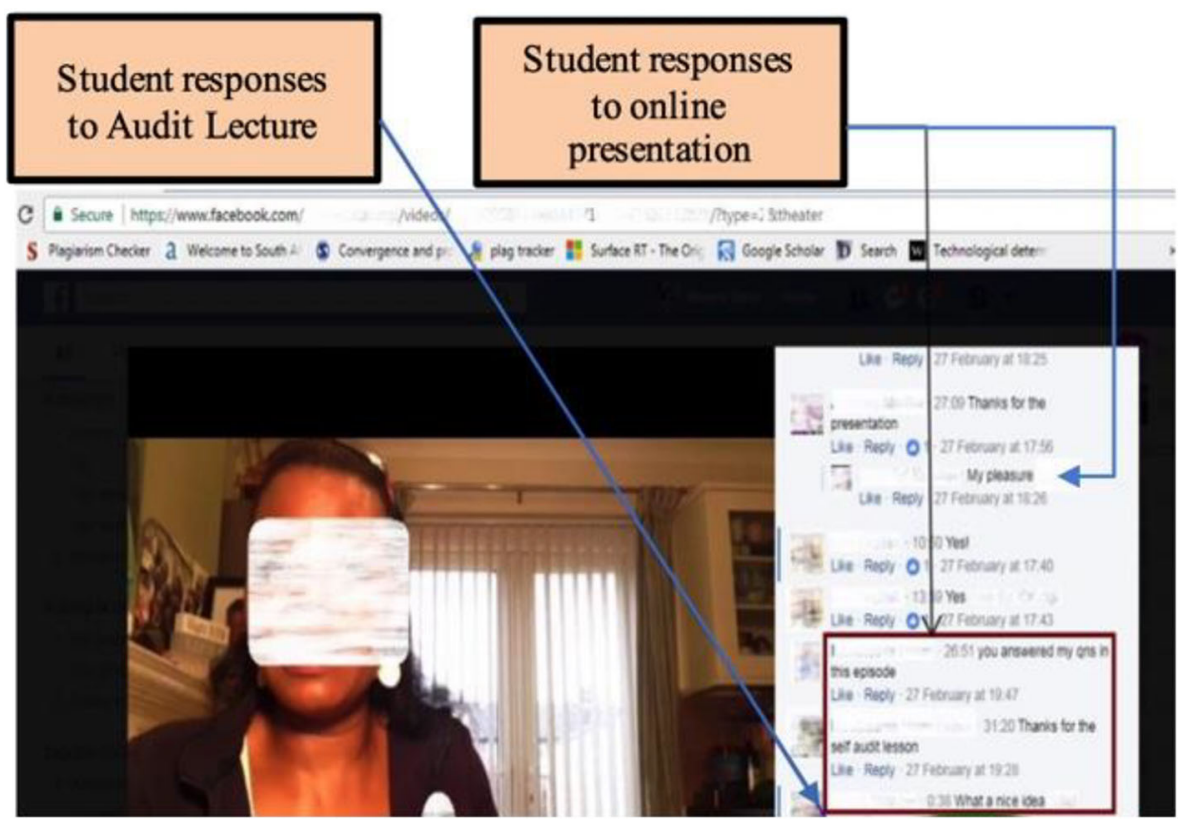

Fig. 2 Screenshot from Aloket's Facebook Live session -

the structured classroom setting. Academics also found that in the Facebook Live streaming sessions, the majority of the students remained for the full duration of the lecture.

Some academics also adopted blogs as an endeavour to enhance their teaching. The use of blogs as a social media technology catered for content delivery, collaborative learning, shared experiences and resources. Academics indicated that the asynchronous nature of blogs provides a changed teaching practice. In using blogs, their posting of comments presented an ideal supportive tool to promote critical thinking (Fig. 3). Some academics at Lethlolo University preferred the use of blogs to encourage students to work collaboratively on particular assignments or projects,

I enjoy blogging and have learned much. It is a kind of friendly way to provide feedback because you can always check on the progress of the assignments as students exchange ideas or upload results of class projects. You can always provide guidance in case you notice that the conversations are going off course .... I like them .... You know... knowledge is built through collaborative processes (Madula).

Academics' blogs were used by students to upload and edit their assignments and complete peer reviews. Blogs presented a seamless communication process, as compared to the frustration of back-and-forth emailing, the LMS, or other traditional ways to collaborate on projects. Academics acknowledged that blogs created a conducive online environment very different to the formal and restrictive classroom environment, or the constraints of the LMS. 


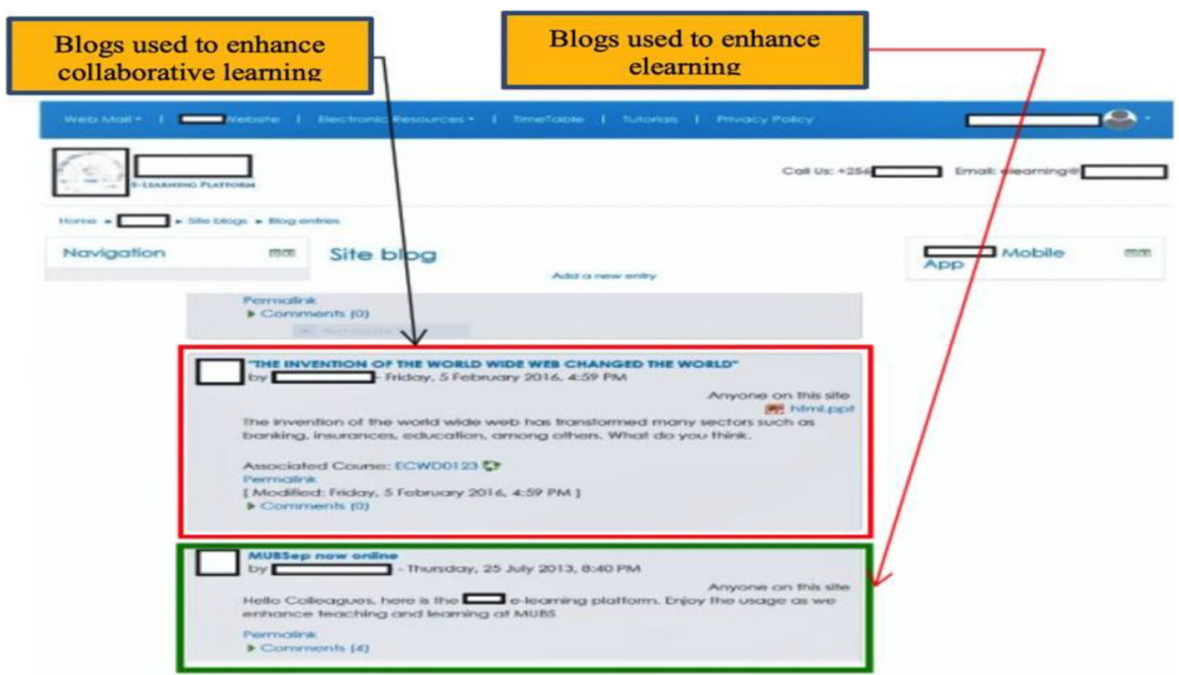

Fig. 3 Screenshot of Madula's blog page used a an elearning platform

I am cautious when I use social media like blogs or Facebook, I am not the "tough/ strict" academic they know in the physical world, I adopt an entirely social face. There other channels [like LMS] that are absolutely professional (Aloket).

\subsection{Beliefs and attitude 'turn'}

Academics realised that teaching in the social media online environment required a change in their beliefs and attitudes. The transition presented new and very different experiences compared to teaching in a face-to-face contact environment. Most academics concurred that changing one's beliefs and attitudes is a catalyst for integration of ICT in teaching;

It has been a significant attitude change for me, with time I have realised that when you incorporate technology, life becomes easy, teaching becomes easy, I tried to explore this online teaching (Muso).

So we need to work on the attitude and the perception, most people have the laptops, there is internet, the students are willing... but I think it's about changing the attitude, encouraging them (academics), telling them the benefits to themselves but also in the learning process (Kaelo).

They (other academics) have always said that some of these courses cannot be taught using ICT, but to me, I think it's an issue of attitude. So, first of all, it is to 
correct their attitude and appreciate and embrace ICT... to know that ICT is a powerful tool in teaching and learning (Makaila).

Yah, definitely, it's an attitude challenge, I think. Ahhhh, that mindset has to be changed such that you are aware that you cannot do without ICT and that it has to be part and parcel of what you do, once people get that, then definitely it won't be hard (Tuba).

\section{Discussion of findings}

Contrary to international trends that suggest that there is a significant shift by academics to use LMS as a teaching-learning technology tool of choice (Walker et al. 2016), the LMS in this study did not present an opportunity for lecturers to change their pedagogy or meaningfully engage with students. The literature suggests that academics perceived the LMS to be useful to enhancing their teaching productivity and effectiveness (Venter et al. 2012). However, in this study academics experienced the LMS to only be useful in enhancing their administrative productivity and effectiveness. Why is this the case? Perhaps the reason for this could have been that unlike their counterparts in first world countries, LMS in this context played out in a resource-constrained environment that was fraught with power failures, lack of network connectivity, frequent downtime and student apathy. Students did not experience the system as appealing and there was a general sense of apathy and resistance to its use. Despite the apparent benefits of the underlying LMS technology as evident in the literature, the core TAM construct of its perceived usefulness did not appeal to academics in this study. Could it also be that academics were not trained to use the system and experienced its 'ease of use' (Davis 1993) as daunting? Clearly, this was an unreliable system that frustrated academics and offered little 'usefulness' for pedagogic change, which contributed to a 'turn away' from the LMS.

The second academic 'turn' was to towards the use of social media tools, which presented an innovative pedagogical approach for curriculum delivery and engagement with students. This change in practice is contrary to the extant literature on the integration of ICT in higher education. Manca and Ranieri (2016) found that social networking tools are among the least used technologies for teaching and learning in that they are pedagogically undervalued and under-exploited. Prescott (2014) and Shelton (2013) cite a number of reasons namely; academics do not view these technologies as having an impact on their pedagogy and lack the confidence to use these tools in practice. Selwyn (2012) found that academics in higher education institutions view social media as a disruptive tool in formal structured teaching approaches. In this study however, academics embraced the benefits of social media networking, such as live streaming and blogs, as a new approach to teaching and learning. What could account for this anomaly? Perhaps the LMS in developed countries is more stable, reliable, user-friendly and operates seamlessly, such that there is no need for academics to explore other technology avenues. However, it would seem the resource constrained 
environment of the Ugandan higher education, motivated academics to explore and dabble with other technology tools that were more readily accessible to students, thus they turn towards the use of social media. Academics tended to first explore with technology becoming familiar with its 'ease of use', and then found pedagogical purpose or 'perceived usefulness' (Davis 1993). In the context of this study, academics' 'turn' towards social media technology seemed to satisfy both TAM constructs of 'ease of use' and 'perceived usefulness' (Davis 1993).

The third 'turn' is the changing beliefs and attitude of academics. Teaching in an online social media environment was new to academics as they explored unfamiliar and untested teaching strategies. It seems as though their personal beliefs informed their practice (Selwyn 2012). Academics explored with new approaches to teaching in an online social networking environment so as to scaffold learning, provide timeous feedback, promote collaboration, and engage with students beyond the confines of their classrooms. Academics' beliefs and attitudes also changed with their practice as they experienced 'ease of use' and appreciated the 'perceived usefulness' of social media to teaching (Davis 1993; Ertmer et al. 2012). This was contrary to the view that social media is a form of disruptive technology (Selwyn 2012). Academics experiences in this study were different, they found that social media enhanced their pedagogical practice and promoted student engagement.

This study found that regardless of the resource-constrained context and pedagogical challenges experienced by academics, their change in attitude demonstrated resilience and determination to embrace ICT in their teaching practice.

\section{Conclusion}

Social media tools stimulated a pedagogical turn of academics. The 'perceived usefulness' and 'perceived ease of use' of social media underpinned by academics' beliefs and resilience promoted technology agency and a pedagogical turn. Academics created a social media teaching-learning environment that was aligned to their pedagogical stance, which served to enhance collaborative learning and student-centeredness. Their rationale for making this pedagogic 'turn' was mainly influenced by limitations academics experienced in a resource- constrained context. Academics used the inherent limitations of a technology-constrained environment as a catalyst to creatively engage with emerging social media technologies to change their pedagogical practice.

Emerging social media technologies provided opportunities for academics that were motivated and passionate, to explore with technology to create innovative ways to teach. This study challenges the notion of academics being bricoleurs, 'making do' with what is at hand (Freathy et al. 2017) and claims that academics are resourceful practitioners, seeking inventive ways to teach more effectively. Social media tools avails academics with particular affordances in the form of flexibility, collaboration, and communication to enhance their pedagogical practice to cater for the twenty-first century learner. Teaching through social media tools not only brings forth new learning opportunities but also new pedagogical challenges. Perceptions that academics held about technology and its perceived usefulness to promote teaching and learning influenced their resilience to persevere with technology. Academics thus 'turned' their 
pedagogy to 'fit' and online teaching environment. The turn was threefold, a turn away from the institutional LMS, a beliefs and attitude turn, and a pedagogical turn.

Further research should explore academics emerging pedagogical practices in their use of social media, eliciting models of innovative good practice. Universities should promote the use of social media as a form of teaching, accompanied by appropriate policy resources and practical guidelines. Recommendation for practice encourages academics to explore and embrace social media tools, not as an 'add-on' technology, but as a structured approach to effective teaching easing pedagogical transition to using Web 2.0 technologies.

\section{References}

Akbar, M. (2016). Digital technology shaping teaching practices in higher education. Frontiers in ICT, 3(1), $1-5$.

Albirini, A. (2006). Teachers' attitudes towards information and communication technologies: The case of Syrian EFL teachers. Computers \& Education, 47, 373-398.

Al-Senaidi, S., Lin, L., \& Poirot, J. (2009). Barriers to adopting technology for teaching and learning in Oman. Computers \& Education, 53(3), 575-590.

Amin, A., \& Rajadurai, J. (2018). The conflict between social media and higher education institutions. Global Business and Management Research: An International Journal, 10(4), 1-11.

Argyris, C., \& Schön, D. A. (1974). Theory in practice: Increasing professional effectiveness. San Francisco: Jossey-Bass.

Beer, C., Jones, D. \& Clark, K. (2009). The indicators project identifying effective learning: Adoption, activity, grades and external factors. In Same places, different spaces. Proceedings Ascilite, Auckland. http://www.ascilite.org.au/conferences/auckland09/procs/beer.pdf9

Bolat, E., \& O’Sullivan, H. (2017). Radicalising the marketing of higher education: Learning from studentgenerated social media data. Journal of Marketing Management, 33(9-10), 742-763.

Cabero-Almenara, J., Arancibia, M. L., \& Del Prete, A. (2019). Technical and didactic knowledge of the Moodle LMS in higher education. Beyond functional use. Journal of New Approaches in Educational Research, 8(1), 25-33. https://doi.org/10.7821/naer.2019.1.327.

Chen, B., \& Bryer, T. (2012). Investigating instructional strategies for using social media in formal and informal learning. The International Review of Research in Open and Distance Learning, 13(1), 87-104.

Chugh, R., \& Ruhi, U. (2018). Social media in higher education: A literature review of Facebook. Education Information Technology, 23, 605-616.

Coates, H., James, R., \& Baldwin, G. (2005). A critical examination of the effects of learning management systems on university teaching and learning. Tertiary Education and Management, 11, 19-36.

Creswell, J. W. (2012). Qualitative inquiry and research design: Choosing among five approaches. London: Sage publications.

Cubeles, A., \& Riu, D. (2018). The effective integration of ICTs in universities: The role of knowledge and academic experiences of professors. Technology, Pedagogy and Education, 27(3), 339-349.

Davies, R. S. (2011). Understanding technology literacy: A framework for evaluating educational technology integration. TechTrends, 55(5), 45-52.

Davis, F. D. (1993). User acceptance of information technology: System characteristics, user perceptions and behavioural impacts. International Journal Man-Machine Studies, 38, 475-487.

Deng, L., \& Yuen, A. H. K. (2011). Towards a framework for educational affordances of blogs. Computers \& Education, 56(2), 441-451.

Denzin, N. K., \& Lincoln, Y. S. (2011). The SAGE handbook of qualitative research. London: Sage.

Dumpit, Z. D., \& Fernandez, C. J. (2017). Analysis of the use of social media in higher education institutions (HEI's) using the technology acceptance model. International Journal of Educational Technology in Higher Education, 14(5), 1-16.

Duta, N., \& Martinez-Rivera, O. (2015). Between theory and practice: The importance of ICT in higher education as a tool for collaborative learning. Procedia - Social and Behavioral Sciences, 180, 14661473. 
Englund, C., Olofsson, A. D., \& Price, P. (2017). Teaching with technology in higher education: Understanding conceptual change and development in practice. Higher Education Research \& Development, 36(1), 73-87.

Ertmer, P. A., Ottenbreit-Leftwich, A. T., Sadik, O., Sendurur, E., \& Sendurur, P. (2012). Teacher beliefs and technology integration practices: A critical relationship. Computers \& Education, 59(2), 423-435. https://doi.org/10.1016/j.compedu.2012.02.001.

Freathy, R., Doney, J., Freathy, G., Walshe, K., \& Teece, G. (2017). Pedagogical Bricoleurs and Bricolage researchers: The case of religious education. British Journal of Educational Studies, 65(4), 425-443. https://doi.org/10.1080/00071005.2017.1343454.

Friesen, N., \& Lowe, S. (2012). The questionable promise of social media for education: Connective learning and the commercial imperative. Journal of Computer Assisted Learning, 28(3), 183-194.

Gaffar, K., Singh, L., \& Thomas, T. (2011). Are we ready for Web 2.0? Evidence from a Caribbean University. The Caribbean Teaching Scholar, 1(2).

Garner, A., \& Bonds-Raacke, J. (2013). Influence of university level direct instruction on educators' use of technology in the classroom. Reading Improvement, 50(4), 145-157.

Guy, R. (2012). The use of social media for academic practice: A review of literature. Kentucky Journal of Higher Education Policy and Practice, 1(2), 1-21.

Harris, J., Mishra, P., \& Koehler, M. (2009). Teachers' technological pedagogical content knowledge and learning activity types: Curriculum-based technology integration reframed. Journal of Research on Technology in Education, 41(4), 393-416.

Hue, L. T., \& Jalil, H. A. B. (2013). Attitudes towards ICT integration into curriculum and usage among university lecturers in Vietnam. International Journal of Instruction, 6(2), 53-66.

Johnson, L., Becker, S. A., Cummins, M., Estrada, V., Freeman, A., \& Hall, C. (2016). NMC Horizon Report: 2016. Higher (Education ed.). Austin: The New Media Consortium.

Kukulska-Hulme, A. (2012). How should the higher education workforce adapt to advancements in technology for teaching and learning? The Internet and Higher Education, 15(4), 247-254. https://doi. org/10.1016/j.iheduc.2011.12.002.

Larsson, A. O., \& Kalsnes, B. (2014). 'Of course we are on Facebook': Use and non-use of social media among Swedish and Norwegian politicians. European Journal of Communication, 29(6), 653-667.

Lederer, K. (2012). Pros and cons of social media in the classroom. Campus Technology, 25(5), 1-2.

Lenhart, A., Purcell, K., Smith, A. \& Zickuhr, K. (2010) Social media and mobile internet use among teens and young adults. Available online at: http://www.pewinternet.org/ /media//Files/Reports/2010/PIP Social Media and Young Adults Report.pdf. Accessed on 13 May 2020.

Loughran, J. (2013). Pedagogy: Making sense of the complex relationship between teaching and learning. Curriculum Inquiry, 43(1), 118-141.

Maleko, M. G., Birevu, M. P., \& Lubega, J. T. (2011). A social networked learning adoption model for higher education institutions in developing countries. On the Horizon, 19(4), 307-320.

Manan, N., Alias, A., \& Pandian, A. (2012). Utilizing a social networking website as an ESL pedagogical tool in blended learning environment: An exploratory study. International Journal of Social Sciences and Education, 2(1), 1-9.

Manca, S. (2020). Snapping, pinning, liking or texting: Investigating social media in higher education beyond Facebook. The Internet and Higher Education, 44, 1-13.

Manca, S., \& Ranieri, M. (2016). Facebook and the others. Potentials and obstacles of social media for teaching in higher education. Computers \& Education, 95, 216-230.

McAliney, P.J. (2013). How undergraduate students use social media technologies to support group project work. Unpublished PhD Thesis. New York University, ProQuest Dissertations Publishing, Steinhardt School of Culture, Education, and Human Development. New York University.

McCarthy, J. (2009). Utilising Facebook: Immersing generation-Y students into first year university. Ergo, 1(2), 39-49.

Mishra, P., \& Koehler, M. J. (2007). Technological pedagogical content knowledge (TPCK): Confronting the wicked problems of teaching with technology. Technology and Teacher Education Annual, 18(4), 2214.

Mostert, M., \& Quinn, L. (2009). Using ICTs in teaching and learning: Reflections on professional development of academic staff. International Journal of Education and Developments in Information and Communication Technology, 5(5), 72-84.

Naidu, E. (2020). After COVID-19 - 'Nothing will be the same'. University world news: Africa edition. https://www.universityworldnews.com/post.php?story=20200406094611664. Accessed 20 May 2020.

Nayar, A. \& Kumar, K.R. (2018). COVID 19 and its mental health consequences. Journal of Mental Health. Online: https://doi.org/10.1080/09638237.2020.1757052, 1, 2. 
Piotrowski, C. (2015). Emerging research on social media use in education: A study of dissertations. Research in Higher Education Journal, 27, 1-12.

Prescott, J. (2014). Teaching style and attitudes towards Facebook as an educational tool. Active Learning in Higher Education, 15(2), 117-128.

Protsiv, M., \& Atkins, S. (2016). The experiences of lecturers in African. Asian and European universities in preparing and delivering blended health research methods courses: a qualitative study. Global Health Action, 9.

Ratto, M., \& Boler, M. (2014). DIY citizenship: Critical making and social media. MIT Press.

Renes, S. L., \& Strange, A. T. (2011). Using technology to enhance higher education. Innovations in Higher Education, 36, 203-213.

Revythi, A., \& Tselios, N. (2019). Extension of technology acceptance model by using system usability scale to assess behavioral intention to use e-learning. Education and Information Technologies, 24, 2341-2355.

Rodriguez, L.F. (2012). The Technology Acceptance Model (TAM) as a Viable Model to Determine the Acceptance of E-learning Technologies in Higher Education Institutions (HEI's). Retrieved from: https://works.bepress.com/luis_rodriguez/8/

Saldana, J. (2012). The coding manual for qualitative researchers. Thousand Oaks: SAGE.

Saunders, G., \& Klemming, F. (2016). Integrating technology into a traditional learning environment. Active Learning in Higher Education, 4(1), 74-86.

Selwyn, N. (2012). Social media in higher education. The Europa World of Learning, 1(10). Retrieved from http://sites.jmu.edu/flippEDout/files/2013/04/sample-essay-selwyn.pdf

Shelton, C. (2013). "Virtually mandatory": A survey of how discipline and institutional commitment shape university lecturers' perceptions of technology. British Journal of Educational Technology, 45(4), 748759.

Sobaith, A. E. E., Moustafa, M. A., \& Ghanforoush. (2016). To use or not to use? Social media in higher education in developing countries. Computers in Human Behavior, 58, 296-305.

Stake, R. E. (2005). Case Studies. In N. K. Denzin \& Y. S. Lincoln (Eds.), Handbook of qualitative research (3rd ed., pp. 443-454). Sage: Thousand Oaks.

Stathopoulou, A., Siamagka, N., \& Christodoulides, G. (2019). A multi-stakeholder view of social media as a supporting tool in higher education: An educator-student perspective. European Management Journal, 37, 421-443.

Tang, Y., \& Hew, K. F. (2017). Is mobile instant messaging (MIM) useful in education? Examining its technological, pedagogical, and social affordances. Educational Research Review, 21, 85-104.

Tearle, P. (2004). A theoretical and instrumental framework for implementing change in ICT in education. Cambridge Journal of Education, 34(3), 331-351.

Tess, P. A. (2013). The role of social media in higher education classes (real and virtual) - a literature review. Computers in Human Behavior, 29, A60-A68.

Thorvaldsen, S., \& Madsen, S. S. (2020). Perspectives on the tensions in teaching with technology in Norwegian teacher education analysed using Argyris and Schön's theory of action. Education and Information Technologies. https://doi.org/10.1007/s10639-020-10221-4.

Venter, P., Jansen van Rensburg, M., \& Davis, A. (2012). Drivers of learning management use in south African open and distance learning institution. Australasian Journal of Educational Technology, 28(2), 183-198.

Walker, D.S., Lindner, J.R., Murphrey, T.P., \& Dooley, K. (2016). The Quarterly Review of Distance Education, 17(2), 41-50. Information Age Publishing.

Publisher's note Springer Nature remains neutral with regard to jurisdictional claims in published maps and institutional affiliations. 